\title{
Devdas, the Aristotelian Tragic Hero of Indian Literature: A Case Study
}

\author{
Yasaman Nouri \\ Kharazmi University of Tehran, Iran. Email: jazmine.nouri@gmail.com
}

\begin{abstract}
India has had a long fascination for the story of Devdas (1917). This tragic novella created by the Bengali author Sarat Chandra Chattopadhyay has always evoked dominant emotions of pity and sympathy. The story has been made into countless movies and newer versions never seem to stop. The story of this doomed love has gained an iconic status and identification in India, equivalent to Shakespeare's Romeo and Juliet, and Devdas's character is recognized as a popular young tragic hero like Romeo. The tragic hero derives from the Greek drama, as elucidated by the criticism of Aristotle in particular. The fourth century Greek philosopher defined tragedy in his Poetics, and laid forth a blueprint for what he saw to work as the perfect, successful tragedy and what makes an ideal tragic hero. In his work Aristotle gives some criteria and specific characteristics that the tragic hero in a successful tragedy should meet. In this paper the character points and the specific characteristics of the hero will be discussed for the case of Devdas, to prove that the character of Devdas in the novella matches the archetype of the tragic hero introduced by Aristotle in his famous literary work Poetics.
\end{abstract}

Keywords: Tragic Hero, Aristotle, Poetics, Devdas

\section{Introduction}

India has had a long fascination for the story of Devdas (1917)-the story of a doomed lover and his inability to take vital decisions in his life. Originally a novella written by Bengali author Sarat Chandra Chattopadhyay in 1901 and later revised and published in 1917, the story of Devdas has been adapted and reinvented across time and cultures, and it has enthralled readers and filmgoing audiences alike for the better part of a century. This creation of the Bengali wordsmith has always evoked dominant emotions of pity and sympathy. This tragic tale has become synonymous with a passionate, intense love that does not find consummation. Devdas remains, to this date, a very popular love story and newer and alternate movie versions never seem to stop, so that it has been made several times in Hindi and other regional languages, the most well-known being, P.C. Barua's version in 1935, Bimal Roy's in 1955, and Sanjay Leela Bhansali's in 2002. The focus of the narrative is the tragic love story of Devdas and Paro A.K.A Parvati, childhood sweethearts torn apart when Devdas is sent to a boarding school in Calcutta, and when he returns Paro proposes they get married. Paro's mother approaches Devdas's mother with a proposal, but is bluntly refused. Devdas, unable to stand up to his parents, rejects her, and Paro, whose parents are humiliated by the rejection, is married off to a wealthy widower. The heartbroken Devdas returns to Calcutta and seeks solace in alcohol and a courtesan named Chandramukhi who falls for him, but whose love remains unrequited by him. Devdas continues on his self-destructive path until on his deathbed, when he travels to Paro's home only to die alone at her doorstep. The (c) AesthetixMS 2016. This Open Access article is published under a Creative Commons Attribution Non-Commercial 4.0 International License (http://creativecommons.org/licenses/by-nc/4.o/), which permits non-commercial re-use, distribution, and reproduction in any medium, provided the original work is properly cited. For citation use the DOI. For commercial re-use, please contact aesthetixms@gmail.com. 
popularity of Devdas over eight decades continues to baffle both critics and cinema historians. The story of this doomed love has gained an iconic status and identification in India, equivalent to Shakespeare's Romeo and Juliet, and Devdas's character is recognized as a popular young tragic hero like Romeo. He has been described as "a virtual Hindu Hamlet in his frustrating inability to act, especially when action seems most necessary" (Creekmur, 2007, p. 180). Devdas has also been called a romantic hero, a Byronic hero, an anti-hero, a self-destructive hero, and most importantly a tragic hero. The tragic hero derives from the Greek drama, as elucidated by the criticism of Aristotle in particular. The fourth century Greek philosopher defined tragedy in his Poetics, and laid forth a blueprint for what he saw to work as the perfect, successful tragedy and what makes an ideal tragic hero. According to Aristotle, a tragic hero is not tragic if he is not able to evoke pity and fear. But to evoke pity and fear the character must have certain characteristics. As Aristotle points out, pity will only arise if a person falls into misery when he does not deserve it and fear will arise when the audience realizes that they could be the one in the character's position (Butcher, 1902, p. 45). What Aristotle wants is a real-life experience for the audience, so that they can identify themselves with the characters, which will lead to proper tragic pleasure or catharsis (Finkelberg, 2006, p. 64). Underlying the actions of the tragic hero is an error, and it is because of this error that he is not able to escape his fate. As "most older tragedies take the name of the tragic hero or heroine as their title" (Jacobus, 2005, p. 16), naming the play for the hero, then, indicates the importance of the character. Hence, Devdas signifies the name of the tragic hero, a noble man, who leads himself to demise. In his work Aristotle enumerates four characteristics that characters in tragedy should meet: they should be "good", "appropriate", "like reality", and "consistent" (House, 1956, p. 83). In this paper the four points are discussed with reference to the characters particularly that of the tragic hero; then at the end, what Aristotle says about the specific characteristics of the hero alone, namely, "hamartia", "discovery", and "reversal of fortune" are discussed with reference to Devdas. Therefore, the purpose of this paper is to prove that the character of Devdas in this story of unfulfilled love matches the archetype of the tragic hero introduced by Aristotle in his famous literary work Poetics.

\section{Goodness}

The first criterion Aristotle gives the character is that "it must be good" (Butcher, 1898, p. 53). A good man, to the ancient Greeks meant much more than it might today. For them, this meant that the hero would be well-known, perhaps even of high stature, but not overly virtuous or morally upright. Aside from money or titles, he may also possess extraordinary abilities. From what Aristotle states in Poetics we can conclude that it is important that the hero, despite having some qualities that normal people have, should not be a common person. Instead, the hero "must be one who is highly renowned and prosperous,-a personage like Oedipus, Thyestes, or other illustrious men of such families" (Butcher, 1898, pp. 45-47). The protagonist in a tragedy is a larger and better version of the rest of us. This is because Aristotle believes that tragedy should be "an imitation of persons who are above the common level" (Butcher, 1898, p. 57). In other words, such a view is the result of a certain aristocratism that Aristotle holds. It is also important for the hero to be prosperous because Aristotle believes "[t]he change of fortune should not be from bad to good, but, reversely, from good to bad" (Butcher, 1898, p. 47). If the hero has much to lose, there is more of a tragic effect than there would be if the character were less prosperous. All of these things, of course, make the inevitable decline of the hero all the more tragic as his transition from good fortune to bad causes pity and fear in the audience. Thus, according to Aristotle nobleness is one side of the goodness of the tragic character. In Chapter XIII of Poetics Aristotle states that the 
tragic hero cannot be a good man coming to bad end, as it is shocking and disturbs faith. He should not also be a bad man coming to good end as it is neither moving, nor moral. The third kind of character he rejects is a bad man coming to a bad end; although it is moral, it is not moving. A bad man, Aristotle claims doesn't "[call] forth pity or fear" (Butcher, 1898, p. 45). Thus, Aristotle disqualifies two types of characters-purely virtuous and thoroughly bad. An ideal character for Aristotle is a rather good man coming to bad end, because he believes that the character must be inherently good-although flawed-to rouse pity and fear in spectacles. Therefore, the ideal tragic hero must be an intermediate kind of a person-neither too virtuous nor too wicked. As Golden (1976) points out, a hero is someone who experiences a fall from happiness into misery, someone with moral integrity and nobility, but not perfect in justice or virtue (p. 25). Aristotle has the presumption that his audience has "a normally balanced moral attitude, by which they cannot give their sympathies to one who is "depraved" or "odious"" (House, 1956, p. 83). For Aristotle the tragedy is "essentially a play in which great moral issues are involved" and that these moral issues "cannot be made plain except in characters who are basically and mainly good" (House, 1956, p. 85). Therefore, "a tragedy explores the space between the "goodness" and "good living" of human beings and how well such human beings actually manage to live" (Nussbaum, 1986, p. 382). Aristotle sees the representation of tragic action to be important since it discloses the truth to the audience that basically good individuals like themselves can go horribly wrong and reap the tragic consequences of what they themselves sow and viewing a tragedy can aid an individual in their moral education. Halliwell (1987) also argues that Aristotle names goodness because of his wish to make tragedy a serious action, wherefore it is necessary that the main character should aim at something that is ethically plausible (p. 140). Thus, aside from nobleness, morality is another factor in determining the goodness of a character.

If we take into account the necessity of nobleness as a characteristic of the tragic hero, Devdas is a prime candidate for being one. He is a young man from a wealthy Bengali Brahmin family in India in the early 190os. They are feudal upper-class landowners. As the story is set in the 2oth century Calcutta, there is a lot of emphasis on class, status, power and money throughout the narrative; and it is one of the reasons why Devdas, the aristocrat and Paro who is from a middle-class merchant family cannot be together easily. Devdas is well-known in his village. He is one of the first people to be sent to a big city to study and he is therefore revered. After coming back he is shown as a smart young man riding a carriage and arriving in style. He is not a common man. He is educated and rich, and has great potential to achieve greatness in his life; this is one of the reasons that his inevitable downfall at the end is all the more tragic, as it seems to be much undeserved. Looking at morality of Devdas, one can also assert that he is indeed an intermediate kind of person. He is not a wicked person, nor is he a virtuous man. He is a good man, but he is definitely flawed. He makes mistakes and pays for them dearly. He is throughout portrayed as a man who is very good and admirable from inside, but is unable to take a decision in life. What causes his downfall is his mistake in treating the situation at hand, not depravity of his character. If Devdas was a truly bad person the readers or the film audience would not sympathize with what he is going through and pity him for all his suffering, and be moved when he dies at Paro's doorstep; and as Aristotle claims one cannot pity a bad man and this proves his goodness.

\section{Appropriateness}

As for the next criterion of the character, Aristotle states that "[t]he second thing to aim at is propriety" (Butcher, 1898, p. 53). What Aristotle means by propriety or appropriateness is the 
"classification" of character (House, 1956, p. 87). And by "class" he means "political and social status, as that was defined by law, by custom, and by function" (House, 1956, pp. 88-89). The concept of status was very important in "medieval political thought". A character raised in a particular environment would have the proper characteristics for being raised in that environment, so "a slave, would become slavelike if not, in the more pejorative sense, slavish". And so "an heir to a monarchy" brought up in the appropriate environment would show an air of "command and authority" (House, 1956, p. 89).

Devdas belongs to the Brahmin caste and the novella presents him as a rich landowner. He is appropriately depicted for his class: an aristocrat. He also acts like an aristocrat. Because of his narrow-minded attitude towards reputation and class, he seems to hold himself in high regard by virtue of being a Brahmin, and consequently treats both Paro and Chandramukhi very badly. Devdas remains incapable of following his desire for Paro, and makes a weak case: family honor and values, and duty to his parents over love. And as for Chandramukhi, although he grows to like her, she is denied by him because of her lower status and occupation. Had Devdas and Paro belonged to the same social status, they could have been happily married. Had Chandramukhi not been a courtesan, she could have married Devdas. These social boundaries are not trespassed by any of the characters, and that leads them to lives of sorrow, even though it saves them from social stigma.

\section{Being True to Life}

Tragic heroes are able to elicit emotions in people because they are just that: people. Even if the characters were deities, Aristotle would argue that they are still relatable to audiences because they are displaying very human characteristics (i.e. jealousy, sadness) in human situations (i.e. infidelity, war, etc.). Being able to see ourselves in their positions is what makes tragic heroes capable of bringing on the appropriate emotional release. The individuals represented have to be individuals like us whose downfall can evoke in us the audience, fear and pity.

In Poetics, the word that Aristotle uses as the third feature of the character, literary means "Likeness", and it is an ambiguous word. Aristotle gives no example in the text of what he really means. Butcher in his translation of Poetics uses "true to life" which seems to clear Aristotle's idea of what he means by "likeness" (House , 1956, p. 91). House (1956) further explains:

[Aristotle] says that characters are either better or worse than ourselves, or just like ourselves: and at the very end of the chapter he says that Comedy makes its personages "worse" and Tragedy makes its personages "better than the men of the present day". It is clear that "ourselves" and "the men of the present day" are here to be equated. Taken together they represent what is now often summed up in the phrase "the man in the street". (pp. 91-92)

Therefore, a hero is someone who is not supposed to be superior or inferior, but rather the same as a normal human being.

We can call Devdas a true to life character. He is an ordinary man with all the problems and weaknesses pertaining to ordinary men. He makes mistakes like us and he suffers like us. Devdas is a man we can love as much as we can admit that he is flawed, perhaps because his flaw is all too understandable. It is simply that he does not comprehend the right thing to do at the right time. We have all made that mistake. When he does return to Paro, it is too late, she is 
married; but he fails to move on. That is why the audience can relate to him and his pain, because they can easily see themselves in him, and that makes him a true to life character.

\section{Consistency}

As House (1956) states; the fourth requirement of the character doesn't need much explanation as it is quite clear what it means. He believes that consistency is a feature needed by all characters. He continues to explain that "[t]he character must be seen as a whole; development must take place according to intelligible principles" (p. 92). According to Halliwell (1987) consistency means that the character is probable and necessary in the situation of the play (p. 142). What Aristotle means by this is that the hero should behave and speak in a manner consistent not only with his own character but with how people would perceive such a person to act and to talk. This means to Aristotle that the tragic hero behaved consistently with his own model of the character. Thus, the kinds of behaviors assigned to a character must not change suddenly and inexplicably; if a character is meant to be represented as indecisive, stubborn, or otherwise inconsistent, this inconsistency must be consistently portrayed.

Is Devdas a consistent character? From his actions and behavior in the story we can come to the conclusion that he shows consistency in his character. Throughout the narrative he is portrayed as an indecisive and hesitant character, and not once he tries to remedy this by taking some action to improve his situation and to get what he wants. Creekmur (2007) states that Devdas is a creature of habit and repetition; and writes, "Devdas seems more fated to repeat actions than to actually fulfill promises" (p. 181). This is played out by his return to his home and the brothel repeatedly. Although it seems Devdas has changed when he returns home from Calcutta (more refined and scholarly), he instantly falls back into his old self by spending all his time with Paro. Instantly the audience/readers are drawn into this relationship and can only hope for the best, but the consistency persists. Devdas leaves yet again, which leads to his repetitive visits to the brothel and back to his village. When he sends Paro that cruel letter in which he tells her he never really loved her, he proves his consistency of character: being fickle, weak, unchangeable and predictable. Devdas's destiny is one of half-commitments, illusions and hesitations. He loves Paro indeed, but cannot or will not risk everything for her, and these character traits do not change throughout the story.

\section{Hamartia}

In Poetics Aristotle tells us that actions are the primary ingredient of tragedy, and that the pivotal action of an exemplary tragedy is a hamartia or error (Butcher, 1898, p. 45). He notes "that the best sort of tragic hero is a man highly esteemed and prosperous who falls into misfortune because of some serious [...hamartia]" (Dodds, 1966, p. 38). Traditionally, hamartia has been identified either as being a tragic flaw-a serious physical, psychological, or moral flaw in an otherwise impeccable character-or as being directly caused by such a flaw. This interpretation is still popular today partly because Butcher in his edition of the Poetics "indicate[s] that the Greek word has a dimension to it that can be designated as a flaw of character" (Golden, 1976, p. 26). This interpretation is however no longer the most popular interpretation among the critics and Adrian Poole (2005) among them also disagrees with it. He states, "[h]amartia is still sometimes thought of as a "fatal flaw", as if it were simply an attribute of character". He believes that "tragedy is concerned with what people do rather than with who they are". Thus, a better translation for hamartia would be "fault", "mistake", or "error". He then continues to observe that, "...however 
much of a character's propensity to error we read into the concept, the primary emphasis seems to be on the error itself, the fault committed". (p. 46) Later on Poole explains this "concept of error" as "making a mistake that has fatal consequences". (p. 47) Robert Hull (1993) also observes that:

Because the arousal of pity and fear is the chief function of tragedy, it is a requirement of a well-constructed plot that the suffering the central character endures be undeserved. For this reason hamartia in this context cannot mean a moral flaw for which an individual is justly punished. The emotional response experienced when witnessing just punishment of the morally culpable is natural, predictable, and pleasurable, but it is not tragic. (p. 288)

From this perspective, hamartia as others may conceive does not indicate "moral faults and failings" and it is not "a moral state; but a specific error which a man makes or commits" (House, 1956, p. 94). What we should remember is that, "the hamartia is accompanied by moral imperfections; but it is not itself a moral imperfection, and in the purest tragic situation the suffering hero is not morally to blame" (House, 1956, p. 95). Therefore, rather than implying some sort of tragic flaw, Aristotle is arguing that a tragic hero's hamartia, from which his destruction stems, is simply his making a mistake, acting in ignorance. Thus, what Aristotle is trying to indicate is that "the fundamental failing of the tragic hero is not moral but intellectual. The cause of the downfall of the hero is not a failure of justice or virtue, but a failure of understanding" (Ahrensdorf, 2009, p. 175). As "the incidents of tragedy are often beyond the hero's control or not closely related to his personality" (Sen, 2014, p. 88), defining Aristotle's hamartia as simply a tragic flaw of some sort or as caused by an individual's flaw of character fails to recognize that Aristotle uses this term to refer to something entirely different from a tragic flaw; namely, "to mean an offense committed in ignorance of some material fact and therefore free from [...wickedness] or [...vice]" (Dodds, 1966, p. 39).

One can argue that Devdas has character flaws; that his tragedy, towards the end, is a result of his character, which is a character of complexities and contradictions. Devdas is a stubborn man, and tends to be cowardly. His lack of courage to fight for his life is one of his biggest weaknesses. He is not firmly able to tell his family that he wants to marry Paro. It is his inability to take the decision of telling his parents that ultimately causes this love to remain unfulfilled. His hamartia could be said to be a result of his character flaws; but it does not really matter; as it is his error of judgment that leads him to his ultimate fate. Unable to firmly tell his parents about wanting to marry Paro, he flees to Calcutta without a second thought about her. His biggest mistake-i.e. his hamartia-occurs when he writes a letter to Paro telling her that their love never existed and that they were just friends. Only after the letter is sent does Devdas realize that his decision was destructive; but by then the wheels of fate are set into motion and he is unable to change his doom. He goes back to his village and futilely tries to persuade Paro that he is ready to do anything needed to save their love. By now, Paro's marriage plans are in an advanced stage, and she declines going back to him and chides him for his cowardice and vacillation.

The novella is said to depict the prevailing societal customs in Bengal in the early 190os, which are largely responsible for preventing the happy ending of the pair's love story. It explores the age-old dichotomy between social norms and human desires. Devdas can be viewed as a social commentary-a reflection on the social norms of the day. Through the story of the unfulfilled love between Devdas and Paro, Sarat Chandra brings out the adverse impact that class hierarchy and social behavioral norms have on people's natural desires, and chain them to a life of sacrifice and suffering. It is believed that the social pressure and customs are the main reason that bring distress to personal lives and prevent the lovers from being together. Paro comes from a family 
that is a caste of traders which takes bride-price, a practice which had a social stigma not attached to the more prevalent bridegroom-price or dowry, so a marriage between her and Devdas seems unlikely. Devdas loves Paro, but he cannot or will not upset societal norms of marrying from another social class; however, "these arguments appear flimsy; for though Parvati's family is not as rich as Devdas's, she is from the same caste as Devdas [They are both Brahmins], and in the feudal Bengal of the early twentieth century, it was not uncommon for a rich man to marry a beautiful, though relatively poor, woman" (Arora, 1997, para. 6). Although fate and society are not kind to him; one cannot make any more excuses for Devdas, as it is his own actions that cause his downfall. He is generally unsure of himself and unable to defy social norms. Throughout the story he wrestles with his internal conflict. He is crushed between family prestige, his cowardice and love, so that he ultimately rejects Paro by running away to Calcutta and sending that short letter. It is the seemingly uncomplicated act of sending a letter-his hamartia-that condemns his relationship and ultimately himself to death.

\section{Discovery}

Discovery or recognition as Aristotle defines it in Chapter XI is "a change from ignorance to knowledge" (Butcher, 1898, p. 41). What he mostly emphasizes and illustrates is "the discovery of identity of persons" (House, 1956, p. 98). But discovery is not only discovery of another person one previously did not recognize, though it usually happens in the plot. It has much more significance and scope. It also indicates "the discovery of whole areas of circumstance, whole states of affairs, about which there was previous ignorance or mistake" (House, 1956, p. 98). Although Aristotle claims that "the recognition which is most intimately connected with the plot and action is ... the recognition of persons", (Butcher, 1898, p. 41) by saying that recognition produces "such terrific changes as the change from love to hate or from hate to love", he inadvertently confirms the broader significance of discovery (House, 1956, p. 98).

Once Devdas knows that he will not be able to unite with his beloved (his parents forbid it), he sends her that cruel letter in which he tells her he never really loved her. Devdas's discovery happens when he realizes his own cruelty and callousness towards Paro, and the terrible mistake he has made in sending her the letter of rejection. Warned by his conscience, he feels guilty and rushes back to her, and upon seeing her, he tries to retreat and say he wrote the words in haste, and that he now realizes he loves her as much as she does. He realizes his folly of upholding the narrow-minded views of the caste system, which an educated man like Devdas can see is wrong. Alas, his remorse and discovery comes too late and his reversal of fortune is set into motion.

\section{Reversal of Fortune}

Peripeteia or reversal as Aristotle defines is "a change by which a train of action produces the opposite of the effect intended, subject always to our rule of probability or necessity" (Butcher, 1898, p. 41). It means the tragic consequences (i.e. reversal) must follow either by probability or necessity from the hero's hamartia. "The best form of recognition" Aristotle states, is "coincident with a reversal". In this conception, hamartia, discovery, and reversal are all interrelated in the fate of the tragic hero. In the finest kind of tragedy the moment of recognition (anagnorisis) depicts a character coming to understand what he has unknowingly done (hamartia), and how his own actions have precipitated his change in fortune (peripeteia). In this sense peripeteia delivers "the idea of the boomerang or recoil effect of one's own actions, of being hoist with one's own petard, falling into the pit that one has dug for [...himself]"(House, 1956, p. 97). Thus, according to 
Aristotle the best form of error is when the hero is on the point of unwittingly committing a mistake and realizes his error when it is too late to correct it, and that is when the reversal of fortune happens. In this sense "reversal involves some violation of expectation" (Davis, 2002, p. $\mathrm{xx})$.

Devdas's reversal of fortune happens on the same pattern. His hamartia (writing the letter plus his inaction in saving their love) leads to his discovery; he realizes what he had lost when Paro gets married to an old man. That is when his reversal of fortune occurs. He grows so depressed at not being able to stop Paro's marriage that he takes to drinking day and night. He blows off his family inheritance on drink. He pines for her and his mistake leads to his isolation. Devdas's self-destructive tendencies occur because he feels like a victim of the situation that he has created for himself. He is so inactive and indecisive in his love story, which sets forth his downward spiral. His constant drinking takes a toll on his health. Once being a respectable son of an aristocrat who used to study in a big city, he becomes a miserable drunkard, residing in a brothel, and wasting his family fortune on alcohol.

The tragic hero's reversal of fortune almost always leads to his death. Therefore, the biggest outcome of peripeteia of tragic hero is death. It is as if the tragic hero cannot escape this fate. The tragic hero "is struggling against something over which [he] really has no control, and the tragedy develops from recognition of the futility of the struggle, leading to the resignation of the tragic hero to his or her fate and indeed even to their embracing that fate" (Bradley, 1919, p. 65). Devdas promises Paro to meet her before he dies, thus predicting his death. In the end, he makes that mysterious final run towards death, thus arousing pity and fear in the audience.

\section{Conclusion}

Devdas-the hero who wills his own doom-is one of the most complex characters of Indian literature, because the choices he makes are detrimental to his fate. The true reason for the success of Devdas as fiction and film seems to be in the subtle nuances, the reasons that provoke the tragedy and loss, and the realization that this tragedy could have been avoided if subtle, small conversations had turned out differently. Devdas is a lover who cannot commit and has a tragic end of his own making. He has all the characteristics attributed to a tragic hero; he is noble and good, he is depicted appropriately for his class, and he shows consistency in his behavior. He is a true to life character like the rest of us. In most movie adaptations Devdas is shown as a victim of society; more a victim than a sinner; and this allows the audience to sympathize with him, but the truth is that his tragedy is a result of his own mistakes. Though he is a likeable character; profound and complex, he does too little, reacts too late and does not take a stand when he should; and makes a terrible mistake by sending the letter, but then that is what makes his character a true tragic hero. His hamartia-sending the letter-triggers his fate. He discovers his error, but it is too late. His reversal of fortune happens when he realizes that what he truly wanted was Paro, but also that it was too late to do anything about it. So, he gradually sinks into a selfpitying stupor of drink and depression, and tries to drown his pain and sorrow in alcohol. The tragedy of Devdas is that he drinks himself to death. But he drinks himself to death not necessarily because of a love lost, but because he cannot find a way to reconcile the person that he is within a societal framework with the loves and relationships that he would like to have. Devdas comes across as a person torn by inner feelings of resentment, anger and doubt, and without a very clear self-understanding. He fails to comprehend the love of both the women until it is spelled out to him, literally, and then tries to run away from both-though he soon regrets his attempt to distance Paro. By then regret is of no use, and he is on the road of no return. Death 
comes, while the love of his life, Paro is even denied a glimpse of his dead body; and this is how the story of Devdas ends.

\section{Works Cited}

Ahrensdorf, P. J. (2009). Greek Tragedy and Political Philosophy: Rationalism and Religion in Sophocles' Theban Plays. New York: Cambridge University Press.

Arora, P. (1997). Devdas: India's Emasculated Hero, Sado-Masochism and Colonialism. Jouvert: A Journal of Postcolonial Studies 1(1). Retrieved from https://english.chass.ncsu.edu/jouvert/vii1/DEVDAS.HTM

Bradley, A. C. (1919). Shakespearean Tragedy. London: Macmillan.

Butcher, S. H. (1898). The Poetics of Aristotle: Edited with Critical Notes and a Translation. (2nd ed.). London: Macmillan.

Chattopadhyay, S. C. (2002). Devdas. (S. Guha, Trans.). New Delhi: Penguin Books India. (Original work published 1917)

Creekmur, C. K. (2007). Remembering, repeating, and working through Devdas. In H. R. M. Pauwels (Ed.), Indian Literature and Popular Cinema: Recasting Classics (pp. 173-190). Abingdon: Routledge.

Davis, M. (2002). Introduction. In S. Benardete, \& M. Davis, Aristotle: On Poetics (pp. xi-xxx). South Bend, Indiana: St. Augustine's Press.

Dodds, E. R. (1966). On Misunderstanding 'the Oedipus Rex'. Greece and Rome, 13(1), 37-49. Retrieved from http://www.jstor.org/stable/642354

Finkelberg, M. (2006). Aristotle and Episodic Tragedy. Greece and Rome, 53(1), 60-72. Retrieved from https://www.jstor.org/stable/412246o

Golden, L. (1976). Toward a Definition of Tragedy. The Classical Journal, 72(1), 21-33. Retrieved from https://www.jstor.org/stable/3296879

Halliwell, S. (1987). The Poetics of Aristotle: Translated, with Commentary. London: Duckworth.

House, H. (1956). Aristotle's Poetics. Bungay, Suffolk: Richard Clay and Company, Ltd.

Hull, R. (1993). Hamartia and Heroic Nobility in Oedipus Rex. Philosophy and Literature, 17(2), $286-94$. Retrieved from https://muse.jhu.edu/article/416112

Jacobus, L. A. (2005). The Compact Bedford Introduction to Drama. New York: Bedford Books.

Nussbaum, M. C. (1986). The Fragility of Goodness: Luck and Ethics in Greek Tragedy and Philosophy. Cambridge: Cambridge University Press.

Poole, A. (2005). Tragedy: A Very Short Introduction. Oxford: Oxford University Press.

Sen, S. (2014). Aristotle's Poetics: A Critical Evaluation. New Delhi: Unique Publishers. 